2014

\title{
Single-Tube Real-Time PCR Assay for Differentiation of Ixodes Affinis and Ixodes scapularis
}

\author{
Chelsea L. Wright \\ Old Dominion University
}

Wayne L. Hynes

Old Dominion University, whynes@odu.edu

Breanna T. White

Old Dominion University

Mindy N. Marshall

Old Dominion University

Holly D. Gaff

Old Dominion University, hgaff@odu.edu

See next page for additional authors

Follow this and additional works at: https://digitalcommons.odu.edu/biology_fac_pubs

Part of the Microbiology Commons, and the Parasitology Commons

\section{Repository Citation}

Wright, Chelsea L.; Hynes, Wayne L.; White, Breanna T.; Marshall, Mindy N.; Gaff, Holly D.; and Gauthier, David T., "Single-Tube Real-Time PCR Assay for Differentiation of Ixodes Affinis and Ixodes scapularis" (2014). Biological Sciences Faculty Publications. 315. https://digitalcommons.odu.edu/biology_fac_pubs/315

\section{Original Publication Citation}

Wright, C. L., Hynes, W. L., White, B. T., Marshall, M. N., Gaff, H. D., \& Gauthier, D. T. (2014). Single-tube real-time PCR assay for differentiation of Ixodes affinis and Ixodes scapularis. Ticks and Tick-Borne Diseases, 5(1), 48-52. doi:10.1016/j.ttbdis.2013.08.003 
Authors

Chelsea L. Wright, Wayne L. Hynes, Breanna T. White, Mindy N. Marshall, Holly D. Gaff, and David T. Gauthier 
Ticks Tick Borne Dis. 2014 February ; 5(1): . doi:10.1016/j.ttbdis.2013.08.003.

\title{
Single-tube real-time PCR assay for differentiation of Ixodes affinis and Ixodes scapularis
}

\author{
Chelsea L. Wright, Wayne L. Hynes, Breanna T. White, Mindy N. Marshall, Holly D. Gaff, \\ and David T. Gauthier \\ Old Dominion University, Department of Biological Sciences, Norfolk, VA 23529, USA
}

\begin{abstract}
Ixodes affinis Neumann (1899) and Ixodes scapularis Say (1821) are tick vectors of the etiologic agent of Lyme disease, Borrelia burgdorferi sensu stricto. Ixodes affinis and I. scapularis are morphologically very similar, and as they are sympatric in the mid- and south-Atlantic U.S. coastal states, their accurate identification is crucial to studies of disease and vector ecology in this area. This work describes a rapid, single-tube SYBR ${ }^{\circledR}$ Green-based real-time PCR assay for differentiation of I. affinis and I. scapularis at all life stages. The assay employs 2 pairs of speciesspecific primers directed against the internal transcribed spacer 2 (ITS2) region of the nuclear rRNA operon. Amplification products for these primer pairs differ in size and may be differentiated with a melt curve analysis. This tool is intended as a supplement to morphological methods for accurate identification of these ticks.
\end{abstract}

\author{
Keywords \\ Ixodes affinis; Ixodes scapularis; Real-time PCR; Identification
}

\section{Introduction}

Ixodes affinis Neumann (1899) and Ixodes scapularis Say (1821) are hard-bodied (ixodid) ticks, both of which are vectors of Borrelia burgdorferi sensu stricto, the agent of Lyme disease (Oliver et al., 2003). Ixodes scapularis, the primary vector of B. burgdorferi s.s. to humans in the eastern United States, has a wide distribution ranging from Florida to Nova Scotia, Canada, and west to North and South Dakota and Mexico (Keirans and Clifford, 1978). Ixodes affinis is more narrowly distributed, with reports of established populations from Florida, Georgia, South Carolina, North Carolina, and Virginia (Clark et al., 1998; Harrison et al., 2010; Nadolny et al., 2011), however its range appears to be expanding (Nadolny et al., 2011). Although I. affinis is rarely known to bite humans (Oliver, 1996), it has a role in the ecological dynamics of Lyme disease in that it shares many of the same hosts as I. scapularis and may thus contribute to the amplification of B. burgdorferi s.s. In the southeastern U.S., I. affinis appears to be more important in the enzootic cycle of $B$. burgdorferi s.s. than I. scapularis (Oliver, 1996; Oliver et al., 2003; Harrison et al., 2010; Maggi et al., 2010).

\footnotetext{
(C) 2013 Elsevier GmbH. All rights reserved.

*Corresponding author. Tel.: +1 757 683-3822; fax: +1 757 683-5283. dgauthie@ odu.edu (D. Gauthier).
}

Publisher's Disclaimer: This is a PDF file of an unedited manuscript that has been accepted for publication. As a service to our customers we are providing this early version of the manuscript. The manuscript will undergo copyediting, typesetting, and review of the resulting proof before it is published in its final citable form. Please note that during the production process errors may be discovered which could affect the content, and all legal disclaimers that apply to the journal pertain. 
Because of the overlapping distribution of I. affinis and I. scapularis in the southeastern U.S., it is necessary to have an accurate method of differentiating these 2 species at any life stage. Ixodes affinis and I. scapularis can be distinguished morphologically (Keirans and Clifford, 1978; Oliver et al., 1987; Durden and Keirans, 1996). Morphological features, however, can be variable and difficult to determine in engorged and damaged specimens, especially nymphs and larvae. Although the seasonal variation in active questing times of $I$. affinis and I. scapularis can serve as an indication of species identity in some areas (Harrison et al., 2010), in other localities both species quest continually throughout the summer months (Nadolny et al., 2011), further complicating the ability to accurately distinguish between the two. Supplemental methods for accurate identification of these 2 species are necessary for retroanalysis of previously examined ticks and reclassification of incorrectly identified specimens, a vitally important task in areas where I. affinis is invading.

In this work, we describe a multiplex real-time PCR (qPCR) assay that supplements morphological identification of I. affinis and I. scapularis. Whereas traditional PCR and sequencing can also be used to accomplish this goal, these procedures can take several days and cost $>10$ USD per sample to accomplish at minimum sequence coverage. In contrast, the assay described here can be performed rapidly $(1 \mathrm{~h})$ in a single tube, at a cost approximately tenfold less than sequencing. Amplification and restriction digestion (PCR-RFLP) has also been used successfully to differentiate I. affinis, I. scapularis, and other Ixodes spp.

(Poucher et al., 1999). PCR-RFLP thus provides a viable alternative to sequencing or qPCR methods, but is more time- and labor-intensive than the latter, as well as potentially more sensitive to single-nucleotide polymorphisms. The qPCR assay presented here is effective for all life stages of I. affinis and I. scapularis and can also be used to differentiate I. affinis and I. scapularis from other Ixodes spp. This assay provides a means to accurately verify morphological identifications and will greatly improve the ability to rapidly and economically identify nymphal and larval Ixodes ticks to species level.

\section{Materials and methods}

\section{Tick collection and morphological identification}

Ticks, including adults, nymphs, and larvae, were collected from several geographic locations in southeastern Virginia in 2010 (Nadolny et al., 2011) and 2011. Questing ticks were collected by dragging white denim cloth flags through areas of vegetation. Engorged $I$. scapularis were collected from white-tailed deer (Odocoileus virginianus) at various hunt stations in southeastern Virginia in October of 2010. Adult and nymphal Ixodes spp. ticks were identified using morphological features (Keirans and Clifford, 1978). Field-collected ticks were kept at $-80^{\circ} \mathrm{C}$ until their DNA was extracted. Questing I. affinis from Beaufort County, North Carolina $(\mathrm{n}=30)$ were collected on flags as described above, and I. affinis from Bulloch County, Georgia ( $\mathrm{n}=5$ ), were collected either from vegetation or from a domestic dog (Canis lupus familiaris). Ten engorged I. scapularis nymphs were acquired from a colony (Wikel strain) located at Old Dominion University. This colony was originally established at the University of Connecticut Health Center (UCHC) using ticks collected in Connecticut as described by Bouchard and Wikel (2005). The I. scapularis (Wikel strain) colony is the reference strain for the Ixodes Genome Project (described in Pagel Van Zee et al., 2007). A single I. scapularis specimen collected from a deer in southeastern Virginia was determined via 16S rRNA gene sequencing to belong to the southern clade of the species (J. Brinkerhoff, pers. communication). Ixodes cookei, I. dentatus, and Ixodes texanus specimens were provided by the Centers for Disease Control and Prevention (CDC) and originally collected from Vermont, New York, and an unknown location, respectively. Ixodes muris specimens were provided by the Maine Medical Center 
Disease Institute. The Ixodes pacificus specimen was collected in California from a domestic dog.

\section{DNA extraction}

DNA from individual Ixodes spp. adults and nymphs was extracted in an area separate from PCR setup. Adult ticks were cut in half longitudinally with a sterile blade prior to DNA extraction. One half of each adult was extracted and the other half stored at $-80^{\circ} \mathrm{C}$. The adult halves and whole nymphs were each disrupted using 1.0-mm glass beads and a MiniBeadbeater-1 (BioSpec Products, Inc., Bartlesville, OK, USA). DNA extraction was performed using the DNeasy Blood and Tissue Kit (Qiagen, Valencia, CA) following the manufacturer's protocol. DNA was eluted in a final volume of $125 \mu \mathrm{L}$ of buffer AE. DNA samples were stored at $-20^{\circ} \mathrm{C}$ until processing.

\section{Primer design}

Primers specific to I. affinis and I. scapularis (Table 1) were designed within the internal transcribed spacer 2 (ITS2) region of the nuclear rDNA transcriptional unit. These primers amplify fragments of 75 and 142-144 bp for I. affinis and I. scapularis, respectively, and are designed in such a manner that the reverse I. affinis-specific primer overlaps the forward $I$. scapularis-specific primer by $15 \mathrm{bp}$. Ixodes scapularis sequence for ITS2 was obtained from GenBank, whereas the ITS2 sequence for I. affinis was obtained by amplification and Sanger sequencing using primers IxSeq5.8SF and 28S R1/1 (Fukunaga et al., 2000; Table 1). ITS2 sequence for I. affinis has been deposited under GenBank \#JX982149. Briefly, ITS2 (and flanking 5.8S and 28S sequence) was PCR-amplified in a $15-\mu \mathrm{L}$ reaction volume containing $1 \mathrm{X}$ buffer (containing $1.5 \mathrm{mM} \mathrm{MgCl}_{2}$ ), 1X Coral Load, $1 \mathrm{X}$ Q-solution, $0.2 \mathrm{mM}$ dNTPs, $1 \mu \mathrm{M}$ forward and reverse primer, and 1.25 U Taq polymerase (all TopTaq, Qiagen, Valencia, CA). Reaction products were verified on $1.5 \%$ agarose gels stained with $\mathrm{SYBR}^{\circledR}$ Safe (Invitrogen, Grand Island, NY) and purified with ExoSAP-IT ${ }^{\circledR}$ (USB/Affymetrix, Santa Clara, CA) according to manufacturer's directions. Purified products were directly sequenced using amplification primers and BigDye ${ }^{\circledR}$ v3.1 reagents (ABI, Carlsbad, CA) followed by analysis on an ABI 3130xl capillary sequencer. Sequence alignment and editing was performed with Geneious v.5 software (Drummond et al., 2010), and primers were designed using Beacon Designer v.7 (PREMIER Biosoft Intl., Palo Alto, CA).

\section{Standard PCR}

A 454-bp fragment of the tick $16 \mathrm{~S}$ mitochondrial rRNA gene was amplified using primers $16 \mathrm{~S}+1$ and $16 \mathrm{~S}-1$. Amplifications were performed in $25-\mu \mathrm{L}$ reaction volumes containing EconoTaq ${ }^{\circledR}$ PLUS $2 X$ Master Mix (Lucigen, Middleton, WI), $0.4 \mu \mathrm{M}$ of each primer, and 2 $\mu \mathrm{L}$ of target DNA. Reaction conditions were an initial denaturation at $95^{\circ} \mathrm{C}$ for $4 \mathrm{~min}$, followed by 35 cycles of $95^{\circ} \mathrm{C}$ for $1 \mathrm{~min}, 50^{\circ} \mathrm{C}$ for $1 \mathrm{~min}$ and $68^{\circ} \mathrm{C}$ for $1 \mathrm{~min}$, and a final extension at $68^{\circ} \mathrm{C}$ for $10 \mathrm{~min}$. Amplified PCR products were electrophoresed on a $2 \%$ agarose gel stained with ethidium bromide.

\section{Real-time PCR}

Amplifications were performed in duplicate in $15-\mu \mathrm{L}$ reaction volumes containing $1 \mathrm{X}$ BioRad iQ ${ }^{\mathrm{TM}}$ SYBR ${ }^{\circledR}$ Green supermix, $0.5 \mu \mathrm{M}$ of each primer (aff_f8, aff_r8, scap_f2.2, scap_r2.2), and $2 \mu \mathrm{L}$ target DNA. Reaction conditions were an initial denaturation at $95^{\circ} \mathrm{C}$ for $3 \mathrm{~min}$, followed by 40 cycles of $95^{\circ} \mathrm{C}$ for $15 \mathrm{~s}, 62^{\circ} \mathrm{C}$ for $30 \mathrm{~s}$, and $72^{\circ} \mathrm{C}$ for $30 \mathrm{~s}$, with a plate read after the $72^{\circ} \mathrm{C}$ (extension) step. A melt curve analysis was performed after amplification by cooling samples to $65^{\circ} \mathrm{C}$ and raising the temperature at $0.5^{\circ} \mathrm{C}$ intervals to $95^{\circ} \mathrm{C}$ for $5 \mathrm{~s} /$ interval and a plate read at each step. Real-time PCR reactions were performed on a CFX96 ${ }^{\mathrm{TM}}$ thermocycler (Bio-Rad, Hercules, CA). 


\section{Statistical analysis}

Student's t-tests were performed using Systat 10 statistical software (Chicago, IL).

\section{Results}

Single-tube, multiplex PCR of specimens identified morphologically as I. affinis $(\mathrm{n}=122)$ or I. scapularis $(\mathrm{n}=89)$ returned strong $(\mathrm{Ct}<20)$ amplification in greater than $90 \%$ of samples for both species (Fig. 1). Three I. affinis and one I. scapularis either did not amplify or returned mean replicate $\mathrm{Ct}$ values of $>30$. One tick identified morphologically as I. affinis and with mean replicate $\mathrm{Ct}$ of $>30$ was subsequently identified via $16 \mathrm{~S}$ mitochondrial rRNA gene sequencing as Ixodes minor (98.5\% similarity with I. minor, GenBank \#AF549841). Two clearly separated ranges of melt peaks were characteristic of $I$. affinis $\left(81.5-82.5^{\circ} \mathrm{C}\right)$ and I. scapularis $\left(84.0-85.5^{\circ} \mathrm{C}\right.$ ) (Fig. 2). Melt peaks of $84.0^{\circ} \mathrm{C}$ were observed in only 2 specimens from the Connecticut-originating I. scapularis colony. In a single adult specimen morphologically identified and sequence-confirmed as $I$. scapularis, replicate melt peaks of $83.5^{\circ} \mathrm{C}$ were returned (Table 2). Sequence data from ITS2 in this individual revealed a G-to$\mathrm{T}$ transversion at position 84 of the amplicon relative to all other individuals sequenced at this locus in the study; it is unknown whether this single base change is sufficient to account for the observed melt peak anomaly. Mean $\mathrm{Ct}$ values among samples with $\mathrm{Ct}<30 \mathrm{did}$ not significantly differ (Student's t-test; $p=0.89)$ with respect to adult $(15.93 \pm 3.00$ [mean \pm S.D.]) or nymphal $(16.02 \pm 3.00)$ life stage, and a single larval I. affinis was amplified with a mean $\mathrm{Ct}$ value of 14.77 .

A subset of samples was sequenced at the 16S mitochondrial rRNA gene and/or ITS2 loci for validation of the qPCR assay. Concordance between $\mathrm{qPCR}$ results and sequence data for both loci was $100 \%$ for both I. affinis and I. scapularis, regardless of life stage. The entire panel of ticks for which both sequence (16S and/or ITS2) and qPCR data were obtained included 53 individuals identified by molecular means as I. affinis, 18 individuals identified as I. scapularis, and one nymphal tick that failed to amplify by the qPCR assay and that was subsequently identified as I. minor based on $16 \mathrm{~S}$ mitochondrial rRNA gene sequencing. The sequenced group comprised 58 adults, 13 nymphs, and 1 larva, with adult and nymphal specimens represented for both I. affinis and I. scapularis. The larval specimen was provisionally morphologically identified as I. scapularis based on the presence of black legs; qPCR and 16S sequence data indicated this individual was I. affinis.

Ixodes spp. other than I. affinis and I. scapularis amplified weakly (>30) or not at all by the qPCR assay. Two Ixodes brunneus individuals amplified with mean $\mathrm{Ct}$ values of 33.05 and 34.86. Melt peaks for these individuals were inconsistent, with one showing peaks at $82.0^{\circ} \mathrm{C}$ and $84.0^{\circ} \mathrm{C}$ for the replicate reactions, and another showing one peak at $82.0^{\circ} \mathrm{C}$ with the replicate peak undetectable. The single I. dentatus specimen amplified with mean $\mathrm{Ct}$ of 33.83 and melt peaks of $74.0^{\circ} \mathrm{C}$ and $84^{\circ} \mathrm{C}$ for the duplicates. No amplification $(\mathrm{Ct}<35)$ was observed for 2 I. muris, one I. pacificus, or one I. texanus specimen. No Ct values of less than 32 were observed in non-Ixodes ticks, with the exception of 2 Dermacentor variabilis, which amplified at mean $\mathrm{Ct}$ values of 24.21 and 28.24. Melt curves for these specimens were inconsistent, with the first at $85.0^{\circ} \mathrm{C}$ in both replicates and the second at $81.5^{\circ} \mathrm{C}$ and $82.0^{\circ} \mathrm{C}$. No amplification $(\mathrm{Ct}<35)$ was observed in no-template control reactions accompanying all experimental runs, and melt curves of $74.0-75.0^{\circ} \mathrm{C}$ were occasionally observed, likely representing primer dimers.

Engorged adult (identified morphologically) and nymphal (Wikel colony) I. scapularis were assayed by qPCR. Mean Ct for this group was $12.88 \pm 3.47$, as compared to unfed $I$. scapularis adults $(16.93 \pm 2.09)$. All ticks in this group demonstrated melt curves consistent 
with I. scapularis. These results indicate engorgement status had no negative effect on the qPCR assay performance.

\section{Discussion}

The multiplex single-tube qPCR assay described in this paper provides rapid, reliable, and accurate means to differentiate between I. affinis and I. scapularis. This will provide a tool for verification of morphological identifications and has potential to refine ongoing studies of the biology, phylogeography, and disease ecology of these important vectors of $B$. burgdorferi s.s. Ixodes affinis appears to be expanding its range northward (Nadolny et al., 2011) and has recently been identified (as larvae and a nymph) on migratory songbirds in Canada (Scott et al., 2012). Given the close morphological similarity between I. scapularis and $I$. affinis, this rapid molecular method will be useful in confirming new range expansions, as well as accurately categorizing individuals from field collections. PCRRFLP-based procedures for differentiation of I. affinis, I. scapularis, and other Ixodes spp. have been described previously (Poucher et al., 1999), however the assay presented here provides an alternative method allowing suitably equipped laboratories to take advantage of reagent and labor savings inherent to $\mathrm{qPCR}$, relative to older amplification and digestion procedures.

Results from the panel of ticks used demonstrated the potential for misidentification of $I$. affinis and I. scapularis by morphological means alone. We found a total of 5 I. scapularis misidentified morphologically as I. affinis (4.1\% of all ticks identified as I. affinis) and 6 cases in which the reciprocal misidentification was made (8.7\% of ticks identified morphologically as I. scapularis, excluding Wikel colony specimens). Of 5 nymphs identified morphologically as I. affinis, 4 were found to be I. scapularis, and one was shown by sequence data to be I. minor after non-amplification with the qPCR assay. Incidentally, this represents the first report from Virginia for I. minor, which has previously been reported in Florida, Georgia, and South Carolina (Keirans and Clifford, 1978; Clark et al., 2001). All nymphs identified morphologically as $I$. scapularis were confirmed via qPCR, although 1 larva and 5 adults identified as I. scapularis were misidentified I. affinis.

Based on the performance of this assay, the following recommendations need to be considered for its use. First, despite a general lack of reactivity with non-target Ixodes and non-Ixodes spp., the assay did show sporadic cross-reactivity with Dermacentor variabilis, and melt peaks, although inconsistent, did overlap with those of I. affinis and I. scapularis. Further, although I. affinis and I. scapularis could be readily differentiated with this assay, it was not designed to positively identify other species. Therefore, it is important that this assay be used as a supplement to morphological identification, rather than as a replacement. Differentiation of Ixodes from non-Ixodes is straightforward even at larval and nymphal stages (Keirans et al., 1996) as is differentiation of most Ixodes adults and nymphs from $I$. affinis and I. scapularis. Larval identification among Ixodes spp. can, however, be somewhat more challenging, and further multiplexing variants of this assay may be useful for specific research projects. Second, we noted no amplification of non-target Ixodes spp. at $\mathrm{Ct}$ values of less than 32 and therefore recommend that $\mathrm{Ct}=30$ be considered a conservative cutoff for determining validity of qPCR-based identification of I. affinis or I. scapularis. We have taken such an approach in Table 2 and note that if a much more conservative approach of setting the cutoff at $\mathrm{Ct}=20$ were used, this would only remove 12 additional individuals from the $\mathrm{Ct}<30$ Ixodes data set $(\mathrm{n}=207)$. As a compromise, we suggest that amplifications with $\mathrm{Ct}>30$ be considered invalid, and those $>20$ be treated with caution, possibly requiring reextraction using the other tick half and assay or sequence confirmation. Melt peaks for individual samples should fall within the ranges of $81.5-82.5^{\circ} \mathrm{C}$ and $84.0-85.5^{\circ} \mathrm{C}$ for $I$. affinis and I. scapularis, respectively. We note here that this assay is not quantitative in 
nature, and $\mathrm{Ct}$ value is in no way intended to be used for differentiating between I. affinis and $I$. scapularis. This is particularly the case as gDNA concentration was not standardized between individuals. Rather, $\mathrm{Ct}$ values are presented as a reference to potential users of this assay and are intended to be used as a quality control measure.

Internal transcribed spacer regions of rDNA transcriptional units are generally much more variable than ribosomal subunits, as they are not subject to the high selective pressure of maintaining specific ribosomal structure. As such, polymorphism in ITS2 sites may conceivably compromise the performance of this assay in genetically divergent populations through the ranges of I. affinis and I. scapularis. This possibility was tested by inclusion in the data set of 35 I. affinis from North Carolina (30 ticks) and Georgia (5 ticks), and $10 I$. scapularis of Connecticut origin (Wikel colony). All of these specimens demonstrated amplification $(\mathrm{Ct}<25)$ and expected melt peaks for the respective species. The existence of a distinct southern population of I. scapularis is well known (Norris et al., 1996; Humphrey et al., 2010), and we performed a search of GenBank for ITS2 sequences from I. scapularis in this region. Unfortunately, several deposited sequences (Rich et al., 1997) of southern (Florida) I. scapularis do not include our primer binding sites in the sequenced range. However, 4 ITS2 sequences of ticks from North Carolina (L22276), and Georgia (L22273, L22274, L22275) were analyzed in silico and were found to be compatible with the $I$. scapularis-specific primers used in this study, producing predicted amplicons of 143-144 bp. We also tested an I. scapularis individual collected in Virginia, but determined via 16S sequencing to belong to the southern clade for this species, and it returned results consistent with other I. scapularis in the study (mean $\mathrm{Ct}=14.07$; melt peak $=85.5$ ). The G-to-T transversion noted at position 84 of the I. scapularis amplicons was also noted in GenBank sequences JQ868566 and L22272 representing I. scapularis from Illinois and New York, respectively (Wesson et al., 1993; Hamer et al., 2012). It is possible that this substitution may lead to lower melt temperatures $\left(83.5^{\circ} \mathrm{C}\right)$ for certain I. scapularis individuals, however the assay should be robust to this possibility as melt ranges for I. scapularis and I. affinis would continue to be separated by a full degree Celsius. This indicates that the qPCR assay presented here should be useful for I. affinis and I. scapularis differentiation at least along the U.S. Atlantic coast. Given the caveats about the ITS2 locus described above, however, it would be advisable for qPCR results from ticks outside the geographic ranges described here to be confirmed by limited sequencing before large-scale assay deployment.

\section{Acknowledgments}

The project described was partially supported by Grant Number K25AI067791 from the National Institute of Allergy and Infectious Diseases. The content is solely the responsibility of the authors and does not necessarily represent the official views of the National Institute of Allergy and Infectious Diseases or the National Institutes of Health. Support was also received from the Old Dominion University Undergraduate Research Apprenticeship Program. We thank Dr. Lance Durden, Georgia Southern University, for the gift of I. affinis specimens from Georgia and Marcee Toliver for I. affinis from North Carolina. We also thank: Jory Brinkerhoff, University of Richmond, for providing a southern-clade I. scapularis specimen; Gabrielle Dietrich, Division of Vector-borne Diseases, CDC, for providing I. cookei, I. dentatus, and I. texanus specimens; Eleanor Lacombe, Maine Medical Center Disease Institute, for providing I. muris specimens; and Kathy Flores for providing an I. pacificus specimen. Dr. Daniel Sonenshine provided useful guidance and manuscript review as well as Wikel colony I. scapularis.

\section{References}

Bouchard, KR.; Wikel, SK. Care, maintenance, and experimental infestation of ticks in the laboratory setting. In: Marquardt, WC., editor. Biology of Disease Vectors. San Diego: Elsevier Academic Press; 2005. p. 705-711.

Clark K, Oliver J Jr, McKechnie D, Williams D. Distribution, abundance, and seasonal activities of ticks collected from rodents and vegetation in South Carolina. J. Vector Ecol. 1998; 23:89-105. [PubMed: 9673934] 
Clark KL, Oliver J Jr, Grego JM, James AM, Durden LA, Banks C. Host associations of ticks parasitizing rodents at Borrelia burgdorferi enzootic sites in South Carolina. J. Parasitol. 2001; 87:1379-1386. [PubMed: 11780825]

Drummond, AJ.; Ashton, B.; Cheung, M.; Heled, J.; Kearse, M.; Moir, R.; Stones-Havas, S.; Thierer, T.; Wilson, A. Geneious computer program, version 5.1. 2010.

Durden, LA.; Keirans, JE. Nymphs of the genus Ixodes (Acari: Ixodidae) in the United States: Taxonomy, identification key, distribution, hosts, and medical/veterinary importance. Lanham, MD: Entomological Society of America; 1996.

Fukunaga M, Yabuki M, Hamase A, Oliver JH Jr, Nakao M. Molecular phylogenetic analysis of ixodid ticks based on the ribosomal DNA spacer, Internal Transcribed Spacer 2, sequences. J. Parasitol. 2000; 86:38-43. [PubMed: 10701561]

Hamer SA, Goldberg TL, Kitron UD, Brawn JD, Anderson TK, Loss SR, Walker ED, Hamer GL. Wild birds and urban ecology of ticks and tick-borne pathogens, Chicago, Illinois, USA, 20052010. Emerg. Infect. Dis. 2012; 18:1589-1595. [PubMed: 23017244]

Harrison BA, Rayburn WH, Toliver M, Powell EE, Engber BR, Durden LA, Robbins RG, Prendergast BF, Whitt PB. Recent discovery of widespread Ixodes affinis (Acari: Ixodidae) distribution in North Carolina with implications for Lyme disease studies. J. Vector Ecol. 2010; 35:174-179. [PubMed: 20618664]

Humphrey PT, Caporale DA, Brisson D. Uncoordinated phylogeography of Borrelia burgdorferi and its tick vector, Ixodes scapularis. Evolution. 2010; 64:2653-2663. [PubMed: 20394659]

Keirans JE, Clifford CM. The genus Ixodes in the United States: A scanning electron microscope study and key to the adults. J. Med. Entomol. 1978; 15(Suppl 2):1-38.

Keirans JE, Hutcheson H, Durden LA, Klompen J. Ixodes scapularis (Acari: Ixodidae): redescription of all active stages, distribution, hosts, geographical variation, and medical and veterinary importance. J. Med. Entomol. 1996; 33:297-318. [PubMed: 8667375]

Macaluso KR, Mulenga A, Simser JA, Azad AF. Differential expression of genes in uninfected and rickettsia-infected Dermacentor variabilis ticks as assessed by differential-display PCR. Infect. Immun. 2003; 71:6165-6170. [PubMed: 14573632]

Maggi RG, Reichelt S, Toliver M, Engber B. Borrelia species in Ixodes affinis and Ixodes scapularis ticks collected from the coastal plain of North Carolina. Ticks Tickborne Dis. 2010; 1:168-171.

Nadolny R, Wright C, Hynes WL, Sonenshine DE, Gaff H. Ixodes affinis (Acari: Ixodidae) in southeastern Virginia and implications for the spread of Borrelia burgdorferi the agent of Lyme disease. J. Vector Ecol. 2011; 36:464-467. [PubMed: 22129422]

Norris DE, Klompen J, Keirans JE, Black WC IV. Population genetics of Ixodes scapularis (Acari: Ixodidae) based on mitochondrial 16S and 12S genes. J. Med. Entomol. 1996; 33:78-89. [PubMed: 8906909]

Oliver J Jr. Lyme borreliosis in the southern United States: a review. J. Parasitol. 1996; 82:926-935. [PubMed: 8973401]

Oliver J Jr, Keirans JE, Lavender DR, Hutcheson HJ. Ixodes affinis Neumann (Acari: Ixodidae): new host and distribution records, description of immatures, seasonal activities in Georgia, and laboratory rearing. J. Parasitol. 1987; 73:646-652. [PubMed: 3598811]

Oliver J Jr, Lin T, Gao L, Clark K, Banks C, Durden LA, James AM, Chandler FW Jr. An enzootic transmission cycle of Lyme borreliosis spirochetes in the southeastern United States. Proc. Natl. Acad. Sci. U S A. 2003; 100:11642-11645. [PubMed: 14500917]

Pagel Van Zee J, Geraci NS, Guerrero FD, Wikel SK, Stuart JJ, Nene VM, Hill CA. Tick genomics: the Ixodes genome project and beyond. Int. J. Parasitol. 2007; 37:1297-1305. [PubMed: 17624352]

Poucher KL, Hutcheson HJ, Keirans JE, Durden LA, Black WC IV. Molecular genetic key for the identification of 17 Ixodes species of the United States (Acari: Ixodidae): A methods model. The Journal of Parasitology. 1999; 85:623-629. [PubMed: 10461941]

Rich SM, Rosenthal BM, Telford SR III, Spielman A, Hartl DL, Ayala FJ. Heterogeneity of the internal transcribed spacer (ITS-2) region within individual deer ticks. Insect Mol. Biol. 1997; 6:123-129. [PubMed: 9099576] 
Scott JD, Anderson JF, Durden LA. Widespread dispersal of Borrelia burgdorferi-infected ticks collected from songbirds across Canada. J. Parasitol. 2012; 98:49-59. [PubMed: 21864130]

Wesson DM, McLain DK, Oliver JH, Piesman J, Collins FH. Investigation of the validity of species status of Ixodes dammini (Acari: Ixodidae) using rDNA. Proceedings of the National Academy of Sciences. 1993; 21:10221-10225. 
$100=$

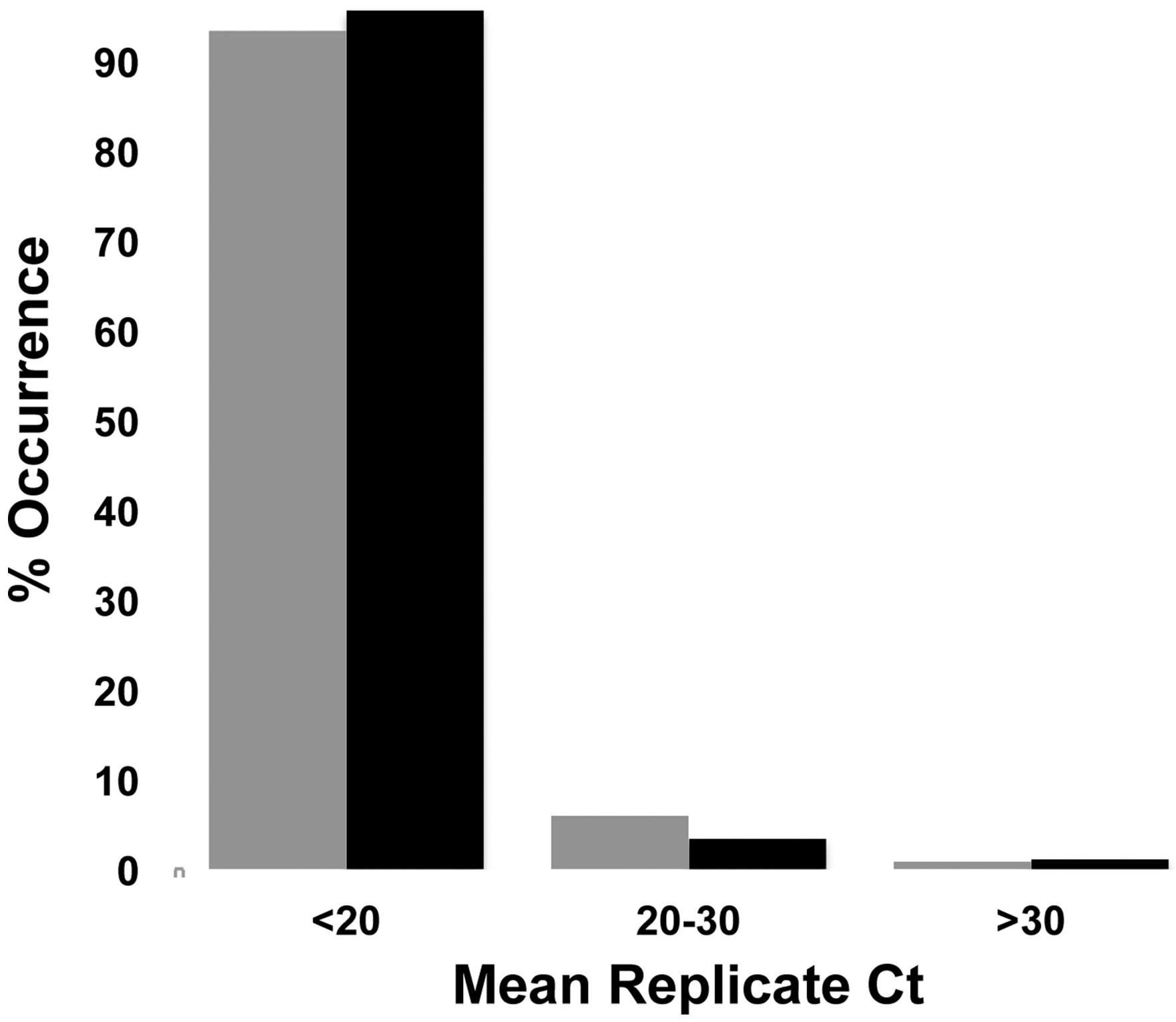

Fig. 1.

Frequency histogram of mean replicate $\mathrm{Ct}$ values for ticks identified morphologically as $I$. affinis (grey bars) or I. scapularis (black bars). 


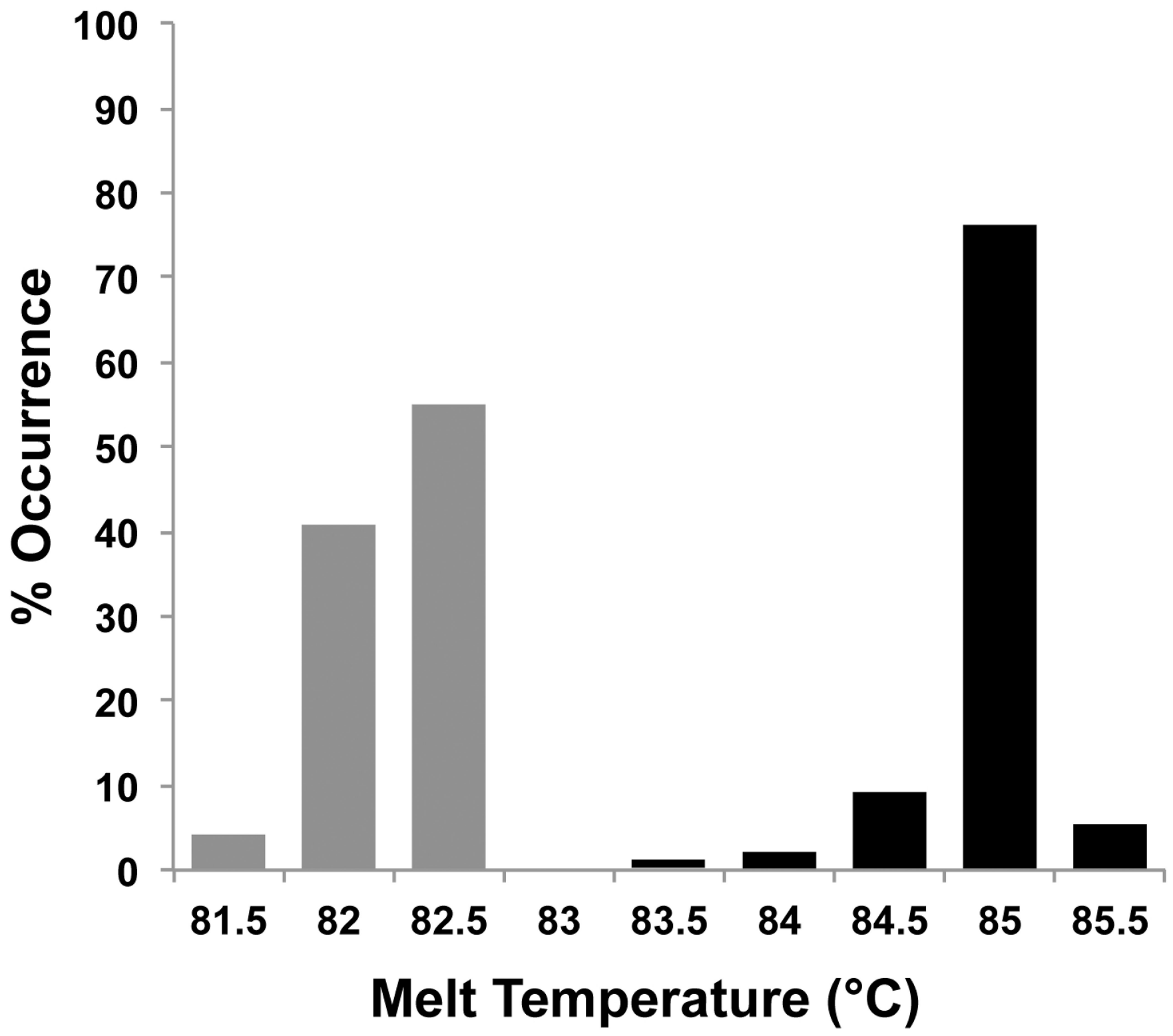

Fig. 2.

Frequency histogram of observed melt temperature range for I. affinis (grey bars) and I. scapularis (black bars). 
Table 1

Oligonucleotide primers used in this study.

\begin{tabular}{|c|c|c|c|c|}
\hline $\begin{array}{l}\text { Primer } \\
\text { name }\end{array}$ & Primer sequence & Locus (position) & $\begin{array}{l}\text { Expected } \\
\text { size (bp) }\end{array}$ & Reference \\
\hline IxSeq-5.8SF & 5'-TCGATGAAGAACGCAGCCAG-3' & 5.8S rRNA gene ${ }^{a}(31-50)$ & 846 & $\begin{array}{l}\text { Modified from } \\
\text { (Fukunaga et al., 2000) }\end{array}$ \\
\hline 28S R1/1 & 5'-TTCTATGCTTAAATTCAGGGGGTTGTC- & $28 \mathrm{~S}$ rRNA gene $(20-46)^{b}$ & & (Fukunaga et al., 2000) \\
\hline $16 \mathrm{~S}-1$ & 5'-GTCTGAACTCAGATCAAGT-3' & 16S mito. rRNA gene $(183-201)^{c}$ & 451 & (Macaluso et al., 2003) \\
\hline $16 \mathrm{~S}+1$ & 5'-CTGCTCAATGATTTTTTAAATTGCTGT-3' & $16 \mathrm{~S}$ mito. rRNA gene $(609-634)^{c}$ & & (Nadolny et al., 2011) \\
\hline aff_f8 & 5'-TGGAAATCCCGCAAATCT-3' & $\operatorname{ITS} 2(214-231)^{a}$ & $75^{d}$ & This study \\
\hline aff_r8 & 5'-CCGTTCCAATCTCCGTTTA-3' & $\operatorname{ITS} 2(277-296)^{a}$ & & This study \\
\hline Scap_f 2.2 & 5'-GCGTTAGAAACGGAGATTTGA-3' & $\operatorname{ITS} 2(271-291)^{a}$ & $142-144^{e}$ & This study \\
\hline Scap_r2.2 & 5'-CCACGAGATTTACATTTGCC-3' & $\operatorname{ITS} 2(394-413)^{a}$ & & This study \\
\hline
\end{tabular}

${ }^{a}$ GenBank \#L22266, Ixodes scapularis.

${ }^{b}$ GenBank \#D88878, Ixodes ricinus.

${ }^{c}$ GenBank \#AB105167, Ixodes acutitarsus.

$d_{\text {in I. affinis. }}$

$e_{\text {in I. scapularis. }}$ 


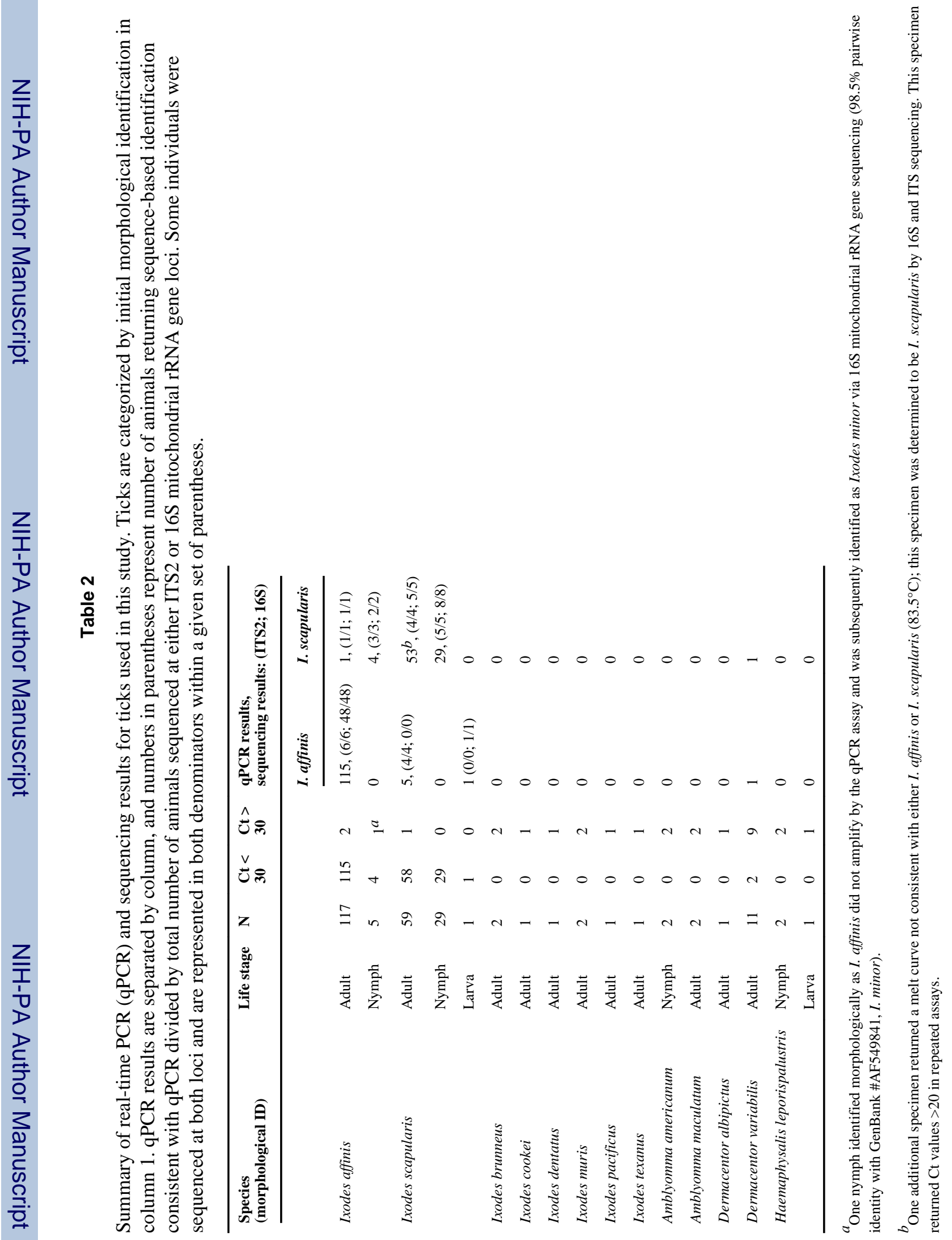

